Nuray Celik

Medeniyet University

https://orcid.org/0000-0002-0423-1987

Melike Yaman

Altinbas University

https://orcid.org/0000-0002-5913-0091

\title{
A new concept in the Turkish legal system: Mobbing
}

\section{A new concept in the Turkish legal system: Mobbing \\ Summary}

Mobbing is a phenomenon which has existed since employment relationships were established in business life. But this issue has been taken into consideration as a legal problem only relatively recently. Thus, within the scope of our work, the definition of mobbing shall be clarified. Moreover, Turkish legislation and judicial opinion regarding mobbing will be analysed.

Keywords: mobbing, employer's responsibilities, Turkish legislation

\section{Terminological considerations}

Mobbing at work includes hostile and unethical actions which are conducted in a systematic manner by one or more persons, usually toward a single employee. Due to the said actions, those persons are pushed into a helpless and defenceless position and held there by means of continuing mobbing activities. ${ }^{1}$

These actions occur very frequently and over an extended period of time. Because of the high frequency and long duration of hostile behaviour, this maltreatment results in mental, psychosomatic, and social misery. ${ }^{2}$ In brief, mobbing means harassing, ganging up on someone or terrorizing them at a workplace. ${ }^{3}$

For the Turkish legal system, mobbing is a new concept. It is, therefore, not regulated conceptually in any domestic legislation. Therefore,

${ }^{1}$ H. Leymann (1996) “The Content and Development of Mobbing at Work." European Journal of Work and Organizational Psychology 1996, vol. 5(2), p. 168.

${ }^{2}$ Ibidem.

${ }^{3}$ Ibidem, p. 165. 
mobbing is defined and developed in case law. First decision regarding mobbing was delivered by 8th Labour Court of Ankara in 2006. In its decision, mobbing was defined as "every kind of maltreatment such as threat, violence, humiliation directed at an employee conducted by his employer, superior, subordinate or colleagues."

Mobbing has not been defined in any Turkish legislation since the Office of Prime Minister issued Circular no. 2011/2 on Psychological Harassment at Workplaces (Mobbing) Prevention. Mobbing is defined in the said document as "emotional abuse which manifests itself through various acts applied intentionally and systematically over a certain period of time, such as humiliating, abusing, intimidating, undervaluing, isolating the employee or damaging his (her) honour and dignity." ${ }^{5}$

\section{Elements of mobbing}

As mentioned above, mobbing is not regulated by Turkish domestic legislation directly. Therefore, elements of mobbing are determined by court decisions and doctrines. To accept a particular action as an instance of mobbing, what is decisive is the character and purpose of a given action. Thus, it should contain the following significant elements:

\section{IIa. Occurrence at the workplace and during the working time}

First characteristic element of mobbing is that the action should take place at a workplace. ${ }^{6}$ The definition of workplace is regulated in the Labour Act no. 4857. According to Article 2 thereof, "All premises used by reason of the nature and execution of the work and organized under the same management, including all facilities adjacent to the establishment such as restrooms, day nurseries, dining rooms, dormitories,

4 8th Labour Court of Ankara 20.12.2006, E.2006/19, K.2006/625.

${ }_{5}^{5}$ Prime Minister's Circular no. 2011/2 on Psychological Harassment at Workplaces (Mobbing) Prevention (available at: https://www.ilo.org/dyn/natlex/docs/ELECTRO NIC/88944/101904/F2096655400/TUR88944.pdf; access date: 15.03.19).

${ }^{6}$ S. SüzeK: İş Hukuku. İstanbul 2018, pp. 119-120; N. Çelik, N. CANiKLIoĞLu, T. Canbolat: İş Hukuku Dersleri. İstanbul 2018, p. 345. 
bathrooms, rooms for medical examination and nursing, places for physical and vocational training and courtyards, as well as the vehicles, are deemed to be parts of the establishment." ${ }^{7}$

According to the definition of workplace, if the action occurred in extensions of establishment such as dining rooms, restrooms, or in vehicles, it will be considered mobbing.

Additionally, the action must occur during the working time. Article 63 and the remainder of the provisions regulate precisely the periods to be considered working time. For instance, overtime work is considered part of working time. In terms of doctrine, if an employer forces an employee to take annual leave, the duration of the leave must be considered part of working time as well. ${ }^{8}$

\section{IIb. Targeted person}

As a victim of mobbing can only be considered a worker of a given entity in a capacity of an employee, a subcontractor, an employee of the subcontractor, or an employer's representative. In exceptional cases, an employer may also be considered a victim of mobbing. ${ }^{9}$

In this context, decision of the Court of Cassation states: "[...] for accepting a behaviour as an instance of mobbing, at least one person must be targeted." 10

\section{IIc. Maltreatment}

Actions against human dignity, such as ill treatment, threat, violation, humiliation are considered as mobbing by the Court of Cassation. ${ }^{11}$

According to the Court of Cassation, mean behaviour of an employer targeted at the entire team of employees is not recognized as mobbing. Because those kind of behaviours must be targeted at par-

7 Translation: https://www.ilo.org/dyn/natlex/docs/ELECTRONIC/64083/77276 /F75317864/TUR64083\%20English.pdf (access date: 15.03.19).

${ }^{8}$ P. SEvinç: İş Hukukunda Mobbing. Master's thesis: University of Bahçeşehir 2018, p. 20.

9 Ibidem, p. 21.

${ }_{10}$ The Court of Cassation Assembly of Civil Chambers 25.09.2013, E.2012/91925, K.2013/1407.

11 9th Civil Chamber of Court of Cassation 28.02.2012, E.2009/30916, K.2012/6093. 
ticular persons. If the employer is simply rude to somebody at a workplace, it shall not be recognized as mobbing. ${ }^{12}$

In addition, harming employee's dignity is not enough to classify a behaviour as an instance of mobbing. A victim must be damaged psychologically. ${ }^{13}$

\section{IId. Systematic repetition of behaviour over a significant period of time}

The already mentioned circular defines mobbing: "[...] various acts applied intentionally and systematically over a certain period of time." Not only the said document but also the Court of Cassation emphasized the continuation factor in its decisions: "[...] as it is seen, to classify a behaviour as mobbing, this situation must be systematic..."14

In one case decided by the Court of Cassation, ${ }^{15}$ the claimant who was a marketing manager claimed that his superior executed some mobbing practices on him by means of oral statements. Over an extended period of time, the defendant told him that he had no future in this company and he would be dismissed soon. The Court of Cassation found such behaviour to be an instance of mobbing.

Furthermore, the Court of Cassation states that systematic behaviours must be performed with an intention of mobbing. That is to say, a sudden outburst of anger or occasional verbal offences cannot be considered as mobbing. As it is explained, those kind of actions must be carried out systematically.

Even the circumstances change and depend on present case, duration of mobbing actions must continue between three months and three years in accordance with Turkish legal doctrine. ${ }^{16}$

\section{Approach to mobbing in the Turkish legal system}

Mobbing actions performed by one's employer or colleagues are considered an infringement of obligations of equal treatment and obliga-

12 22th Civil Chamber of Court of Cassation 22.05.2014, E.2013/11788, K.2014/14008.

13 N.G. Kantarci: Türk İş Hukukunda Mobbing. Ankara 2016, p. 29.

14 22th Civil Chamber of Court of Cassation 16.11.2017, E.2017/43308, K.2017/25088.

15 9th Civil Chamber of Court of Cassation 05.07.2018, E.2015/21084, K.2018/14846.

16 S.Y. LokmanoĞLu: İşyerinde Psikolojik Taciz Mobbing. Ankara 2017, p. 49. 
tions to protect personal rights. ${ }^{17}$ In this study, legislation based on the above-mentioned obligations will be examined.

\section{IIIa. Legislation based on an employer's obligation of equal treatment}

As already explained, the concept of mobbing is not regulated in detail in the Turkish legal system. It is developed by the case law. The only direct regulations are the above-mentioned circular and Act no. 6701 of the Turkey Human Rights and Equality Institution. This act forbids discrimination, and lists nine types thereof, mobbing being one of them.

Article 6 prohibits the employer to discriminate against the employee during the employment relationship. According to Article 25, in the event of violation of prohibition of discrimination, a person responsible for the violation shall be imposed an administrative fine from 1,000 TRY to 15,000 TRY.

Labour Act no. 4857 prohibits discrimination as well. Article 5 thereof states: "No discrimination based on language, race, sex, political opinion, philosophical belief, religion and sex or similar reasons is permissible in the employment relationship. Unless there are essential reasons for differential treatment, the employer must not make any discrimination between a full-time and a part-time employee or an employee working under a fixed-term employment contract (contract made for a definite period) and one working under an open-ended employment contract (contract made for an indefinite period). Except for biological reasons or reasons related to the nature of the job, the employer must not make any discrimination, either directly or indirectly, against an employee in the conclusion, conditions, execution and termination of his (her) employment contract due to the employee's sex or maternity. [...] If the employer violates the above provisions in the execution or termination of the employment relationship, the employee may demand compensation up to his (her) four months' wages plus other claims of which he (she) has been deprived [...]."18 In addition, employee has a right to terminate the contract of employment with a rightful reason.

17 For further information see also: N. Çelik, N. CaniklioğLu, T. Canbolat: $\dot{I}_{s ̧} H u-$ kuku Dersleri..., pp. 345-352.

18 Translation: https://www.ilo.org/dyn/natlex/docs/ELECTRONIC/64083/77276 /F75317864/TUR64083\%20English.pdf (access date: 15.03.19). 
Additionally, Article 3 of the Turkish Criminal Code stipulates that discrimination must not be practices between persons. Besides, if a person is harassed sexually by a superior or a co-worker, the person who performs such acts will be sentenced to punishment subject to Article 105 of the Turkish Criminal Code.

\section{IIIb. Legislation based on an employer's obligations to protect personal rights}

Mobbing in work life is considered as an infringement of personal rights of employees. By this action, an employee's psychological wellbeing and mental health are damaged. Therefore, the concept of mobbing is interpreted under the duty of an employer's obligations to protect personal rights. ${ }^{19}$

Obligations of employer to protect personal rights are addressed in detail in the Occupational Health and Safety Act, in the Turkish Civil Code and the Turkish Code of Obligations.

Under Article 4 of the Occupational Health and Safety Act no. 6331, the employer must take all necessary measures and maintain order to ensure health and safety of workers in every aspect of the work. If the employer acts contrary to this provision, he or she shall be liable to pay a fine. Mobbing is one of the occupational health and safety risk factors in the psychosocial risk group. In other words, mobbing, to which the employee is exposed in the workplace, results in insufficient occupational health and safety measures implemented in such a workplace. Therefore, according to the Occupational Health and Safety Act employees exposed to serious, imminent, and unavoidable danger have the right to abstain from work under Article 13.

Furthermore, Article 417 of the Turkish Code of Obligations regulates the protection of employee's personality. According to this provision, the employer is obliged to protect and respect employee's personality during the execution of employment relationship. Pursuant to Article 417, the employer is responsible for taking necessary measures to prevent employee suffering from emotional or sexual abuse at workplace. If the employer violates this provision, he or she is

19 S. Helvacı: Gerçek Kişiler. İstanbul 2013, p. 114; S. Y. LoKmanoĞLu: İşyerinde Psikolojik Taciz Mobbing..., p. 79. 
obliged to compensate moral and material damages incurred by the employee.

As already mentioned, mobbing actions are considered violation of employee's personal rights. Therefore, under articles 24 and 25 of the Turkish Civil Code, the employee subject to assault on his or her personal rights may claim protection from the court. In addition, such an employee may demand from the court to take actions to prevent the assault, stop the threat and determine the unlawful consequences of the assault, even when it has already been discontinued. ${ }^{20}$

\section{Current situation in Turkey}

In accordance with the legal situation in Turkey, the victim of mobbing takes the following legal actions:

1. If the mobbing actions at the workplace constitute a crime within the scope of the Turkish Criminal Code, a criminal complaint may be filed.

2. According to the Turkish Code of Obligations, Article 417, if the perpetrator of mobbing is the employer, the employee may claim moral and material damages due to a breach of contract.

3. If the conditions regulated in the Turkish Civil Code Article 25 are met, the employee may demand from the judge to take an action for prevention of assault, suspension of this threat, and determination of the unlawful consequences of the assault.

4. The employee may terminate his employment contract due to a justified reason subject to Article 24 of the Labour Act.

5. If mobbing occurs at the workplace and it is based on discrimination, the employee may claim discrimination compensation. In addition, victims of mobbing may seek the protection to the Turkey Human Rights and Equality Institution.

6. In the event of a serious, imminent, and unavoidable danger; employees shall leave their workplace.

Recently, the Ministry of Family, Labour and Social Services takes special measures in order to prevent mobbing at workplace. The Ministry provides psychological assistance to the victims of mobbing and

${ }^{20}$ For further information see also S. Y. LoKmanoĞLu: İsyerinde Psikolojik Taciz Mobbing..., pp. 118-129. 
offers counselling services on the "ALO 170" phone line. In years 2011-2016 38,262 employees in Turkey reported that they had been victims of bullying by calling this support line. It was said that $81 \%$ of those who explained that they had been victims of mobbing were employees of a private sector. ${ }^{21}$ In our opinion, when the number of people who call the mobbing support line and get help is compared to the entire working population in Turkey (in 2019 it was over 28 million people), it is clear that a lot of people are exposed to mobbing on a national scale.

\section{Conclusions}

Mobbing is a new concept in the Turkish legal system. Definition of mobbing (from Circular No. 2011/2) enables us to deduce material elements of mobbing. To accept the acts as mobbing, such acts must occur at workplace and during working time, performed against targeted person or groups, including maltreatment and applied systematically during a significant period of time. Those elements are determined and developed by the case law, especially the Court of Cassation.

In our opinion, the above-mentioned legal provisions are not sufficient to protect employees from mobbing actions at workplace. Therefore, more comprehensive codification is necessary. It would be appropriate for the victims of mobbing to have a psychologist at the workplace, which would be considered an occupational safety and health measure by the employer. We believe that it is necessary at certain hours of the week according to the risk group, both in terms of ensuring occupational health and safety and in terms of treating the employees who are exposed to mobbing. While this practice is important in terms of providing occupational health and safety measures, the problems experienced by victims of mobbing will not be resolved promptly. However, such action will definitely help the victim of mobbing, enable the employer to take appropriate preventive measures in the field of health and safety, and also make employees work more efficiently.

${ }^{21}$ Available at: https://mobbing.org.tr/genel/turkiyede-uzun-calisma-saatleri-mob bing-ve-intihar-egilimi/ (access date: 15.03.19) 


\section{Bibliography}

Kantarci N.G.: Türk Işs Hukukunda Mobbing. Ankara 2016.

Çelik N., Caniklioğlu N., Canbolat T.: İş Hukuku Dersleri. İstanbul 2018. Helvaci S.: Gerçek Kişiler. İstanbul 2013.

Kazancı Jurisprudence Search Engine (www.kazanci.com).

Leymann H.: "The Content and Development of Mobbing at Work." European

Journal of Work and Organizational Psychology 1996, Vol. 5(2).

LokmanoĞLu S.Y.: İsyerinde Psikolojik Taciz Mobbing. Ankara 2017.

SüzeK S.: İş Hukuku. İstanbul 2018.

SEvinç P.: İş Hukukunda Mobbing. Master's thesis: University of Bahçeşehir 2018.

\section{Nowe zagadnienie $\mathrm{w}$ tureckim systemie prawnym - mobbing}

\section{Streszczenie}

Mobbing to zjawisko, które istnieje w relacjach zawodowych od czasu ustanowienia stosunków pracy. Kwestia mobbingu jednak rozpatrywana jest jako zagadnienie prawne dopiero od niedawna.

Nasz artykuł skupia się na doprecyzowaniu definicji mobbingu. Panadto w naszej pracy omówione i przeanalizowane zostały tureckie przepisy prawne oraz opinie prawne dotyczące mobbingu.

Słowa klucze: mobbing, odpowiedzialność pracodawcy, tureckie przepisy prawne

\section{Nouvelles questions dans le système juridique turc - harcèlement professionnel}

\section{Résumé}

Le harcèlement est un phénomène qui existe dans les relations professionnelles depuis l'établissement des relations de travail. Pourtant, c'est depuis peu que le harcèlement professionnel est considéré comme une question juridique.

Notre article vise à préciser la définition du harcèlement professionnel. De surcroît, dans notre travail ont été présentées et analysées les dispositions juridiques turques ainsi que les opinions juridiques concernant le harcèlement professionnel.

Mots clés: harcèlement professionnel, responsabilité de l'employeur, dispositions juridiques turques 